\title{
Developmental Expression of PEPT1 and PEPT2 in Rat Small Intestine, Colon, and Kidney
}

\author{
HONG SHEN, DAVID E. SMITH, AND FRANK C. BROSIUS III \\ College of Pharmacy and Upjohn Center for Clinical Pharmacology [H.S., D.E.S.], Division of \\ Nephrology, Department of Internal Medicine [F.C.B.], The University of Michigan, Ann Arbor, Michigan \\ 48109, U.S.A.; and Ann Arbor Veterans Affairs Medical Center [F.C.B.], \\ Ann Arbor, Michigan 48105, U.S.A.
}

\section{ABSTRACT}

\begin{abstract}
Mammalian peptide transporters (PEPT1 and PEPT2) play a pivotal role in the absorption of small peptides from the intestine and kidney, respectively, and in the disposition and targeting of peptide or mimetic drugs. However, there are few reports on the molecular basis of their regulation, especially in the young. The aim of this study was to determine the developmental expression of intestinal and renal oligopeptide transporters in rats from embryonic to adult ages. Intestinal segments were collected (i.e. duodenum, jejunum, ileum, and colon) along with whole kidney, and their mRNA and protein levels were measured. Expression levels of PEPT1 were maximal 3-5 d after birth in the duodenum, jejunum, and ileum, and then declined rapidly. Expression was increased transiently at d 24, most notably in the ileum. Adult protein levels were approximately $70 \%$ of that observed on d 3-5. Significant PEPT1 expression was observed in colon during the first week of life, but levels were undetectable shortly thereafter through adulthood. PEPT1 and PEPT2 expression is less regulated in rat kidney and more pronounced in older
\end{abstract}

animals. Peptide transporters were also present as early as d 20 of fetal life for all tissues tested. These results are unique in providing the developmental expression of peptide transporter mRNA and protein in distinct regions of the small intestine, colon, and kidney in rat. Our findings suggest that intestinal expression of PEPT1 is induced postpartum, possibly by suckling, and again at the time of weaning, and that the colon may participate in peptide transport early in life. (Pediatr Res 49: 789-795, 2001)

\section{Abbreviations:}

PEPT1, intestinal oligopeptide transporter

PEPT2, renal oligopeptide transporter

PHT1, peptide/histidine transporter

GlyGly, glycylglycine

GlyPro, glycyl-L-proline

GlySar, glycylsarcosine
Expression and molecular cloning studies have resulted in the identification of two distinct proton-coupled oligopeptide transporters in rabbit $(1-3)$, rat $(4-6)$, and human $(7,8)$ (i.e. PEPT1 as low-affinity carrier, PEPT2 as high-affinity carrier). The proteins range in size from 707 to 729 amino acids in various species, with high homology between species for a given transporter (approximately 80\%) and less homology between transporters for a given species (approximately 50\%). The gene products, as predicted by hydropathy analysis, contain 12 membrane-spanning domains and a large extracellular loop between transmembrane domains 9 and 10. The encoded proteins have a number of potential $N$-glycosylation as well as protein kinase recognition sites, which suggests that the trans-

Received August 23, 2000; accepted January 9, 2001.

Correspondence and reprint requests: David E. Smith, Ph.D., 4302A Upjohn Center, 1310 E. Catherine Street, The University of Michigan, Ann Arbor, MI 48109-0504, U.S.A.; e-mail: smithb@umich.edu

Supported in part by grant R01 GM35498 from the National Institutes of Health.

Presented in part at the 32nd Annual Meeting of the American Society of Nephrology, Miami Beach, FL, November 1999. porters may be regulated by reversible phosphorylation. More recently, a third peptide transporter, PHT1, was cloned from rat brain (9). Encoding a protein of 572 amino acids, hydropathy analysis predicts the presence of 12 transmembrane domains. There are also multiple $N$-glycosylation sites in the hydrophilic extracellular loop of PHT1, along with potential sites for protein kinase C-dependent phosphorylation. PHT1 is novel in that it transports histidine, as well as small peptides, with high affinity and in a proton gradient-dependent manner. Although expressed in the brain and eye, PHT1 is not found in the intestine or kidney and shows little homology to PEPT1 and PEPT2 ( $<20 \%$ amino acid identity). Its physiologic role remains to be determined.

Mammalian peptide transporters (PEPT1 and PEPT2) are steeped in nutritional, pharmacologic, and clinical importance. The localization of PEPT1 (in intestine and kidney) and PEPT2 (in kidney) is vital for their physiologic role in absorbing small peptides arising from digestion of dietary proteins in the small intestine, as well as in reabsorbing filtered peptides generated 
from luminal peptidases in the kidney $(10-12)$. In addition, several pharmacologically active drugs are accepted by the intestinal and renal oligopeptide transporters (e.g. aminocephalosporins, aminopenicillins, angiotensin-converting enzyme inhibitors, nucleoside ester prodrugs) (13-16). As a result, this novel transport system is an important determinant of drug disposition, toxicity, and therapeutic efficacy. Some investigators have advocated the use of short-chain peptides as substitutes for free amino acids in enteral and parenteral solutions (17-19). This strategy may be particularly advantageous in newborns because amino acids were much more effectively absorbed in the intestine as peptide-bound nitrogen when compared with adults $(17,18)$. These studies and others $(20$, 21) suggest that the expression of PEPT1 may change markedly during development. However, the molecular basis for age-related alterations of peptide transport activity in the intestine is unclear inasmuch as previous studies did not measure protein levels of PEPT1 and sampling was limited to jejunal tissue alone (5). Furthermore, there is no information on the developmental aspects of PEPT1 and PEPT2 in the kidney. With this in mind, the objective of this study was to determine the developmental expression of intestinal and renal oligopeptide transporters in rats from embryonic to adult ages.

\section{METHODS}

Animals. Pregnant Sprague Dawley rats were delivered at d 16 and 21 of gestation from Charles River Laboratories (Portage, MI, U.S.A.) and housed at the University of Michigan Animal Care Facility. Litters were born at $22 \mathrm{~d}$ gestation and were kept with their mothers until they were $21 \mathrm{~d}$ old. Animals were routinely weaned at $21 \mathrm{~d}$ to a standard laboratory diet (Rodent Diet 5001, PMI Nutrition International, St. Louis, MO, U.S.A.). Rats of either sex were killed at $\mathrm{d} 17$ and 20 of gestation, and at 1, 3, 5, 7, 14, 21, 24, 28, 60, and $75 \mathrm{~d}$ (adult) after birth. Intestinal segments were then collected (i.e. duodenum, jejunum, ileum, and colon) along with whole kidney (owing to its smaller size). Embryonic colon samples were not collected (because of the uncertainty of obtaining intact tissue at this developmental stage). For each developmental age, samples were pooled using one to three pups per litter for a total of three to 18 animals per preparation. Data points represent the mean of two to three independently generated preparations. Animals were anesthetized under hypothermic conditions with $\mathrm{CO}_{2}$ before decapitation. All animal procedures and study protocols were approved by the University of Michigan Committee on Use and Care of Animals.

Northern blot analysis. Total RNA was prepared from different regions of the small intestine, and from the colon and kidney of developing rats. These regions were homogenized in Tri-Reagent (Molecular Research Center, Cincinnati, OH, U.S.A.), and RNA was obtained using a modification of the method of Chomczynski and Sacchi (22), as described by the manufacturer (23). Because of low-intensity signals in kidney, poly $(\mathrm{A})^{+}$RNA was prepared from this tissue using guanidium isothiocyanate followed by cesium chloride gradient centrifugation and oligo(dT)-cellulose chromatography. Northern analyses were then performed for rat PEPT1 and PEPT2 as de- scribed previously (12). Briefly, $15 \mu \mathrm{g}$ of total RNA from small intestine or colon or $4 \mu \mathrm{g}$ of poly(A) ${ }^{+}$RNA from kidney were electrophoresed overnight on $1 \%$ agarose gels containing $6 \%$ formaldehyde and transferred with $10 \times \mathrm{SSC}(1 \times \mathrm{SSC}$ is $150 \mathrm{mM} \mathrm{NaCl}$ and $15 \mathrm{mM}$ sodium citrate, $\mathrm{pH}$ 7.0) to nylon membranes by capillary action. cDNA probes of rat PEPT1, PEPT2, and $\beta$-actin were labeled with $\left[{ }^{32} \mathrm{P}\right] \mathrm{dCTP}$ using a random labeling kit (Boehringer Mannheim Gmbh, Mannheim, Germany). Hybridization of the nylon membrane to ${ }^{32} \mathrm{P}$-labeled cDNA was performed overnight in a solution of $50 \%$ formamide, $6 \times$ SSC, $2.5 \times$ Denhart's solution, $0.5 \%$ SDS, and 150 $\mu \mathrm{g} / \mathrm{mL}$ salmon sperm DNA at $45^{\circ} \mathrm{C}$, and then washed several times at $65^{\circ} \mathrm{C}$ in $0.1 \times \mathrm{SSC}$ plus $0.1 \% \mathrm{SDS}$. Autoradiography was performed by using a phosphorimager, and signal intensities were quantified by computerized densitometric analysis (Imagequant v1.2 software, Molecular Dynamics Inc., Sunnyvale, CA, U.S.A.). Data were normalized to $\beta$-actin to control for variability in RNA loading.

Membrane preparation. Brush border membranes were prepared from intestinal segments and from the colon and kidney of developing rats, as described previously (24). In brief, tissue samples were homogenized in buffer $1(10 \mathrm{mM}$ mannitol, 0.1 $\mathrm{mM}$ phenylmethylsulfonyl fluoride, $2 \mathrm{mM}$ Tris, $\mathrm{pH}$ 7.0) for 5 min in a Waring blender (VWR, Chicago, IL). Calcium chloride was added to the homogenate (final concentration, 10 $\mathrm{mM}$ ), which was stirred and allowed to stand for $15 \mathrm{~min}$ (step 1). The suspension was then centrifuged at $500 \times g$ for $12 \mathrm{~min}$, and the resulting supernatant was centrifuged at $16,000 \times g$ for $15 \mathrm{~min}$ (step 2). The pellet from this high-speed spin was suspended in buffer 1 using a glass-Teflon homogenizer. Steps 1 and 2 were repeated on this homogenate, and the resultant pellet was then suspended in buffer 2 (100 $\mathrm{mM}$ mannitol, 20 $\mathrm{mM}$ HEPES, $\mathrm{pH}$ 7.4). The suspension was centrifuged at 2,000 $\times g$ for $15 \mathrm{~min}$, and the resultant supernatant was centrifuged at $47,000 \times g$ for $15 \mathrm{~min}$. The remaining pellet, which contained enriched brush border membranes, was then suspended in a small volume of PBS by repeated passage through an 18 -gauge needle. All procedures were performed on ice or at $4^{\circ} \mathrm{C}$. Protein concentrations were determined by the Coomassie blue binding method (25) with BSA as the protein standard.

Immunoblot analysis. Brush border membranes were solubilized in sample loading buffer (1\% SDS, $50 \mathrm{mM}$ Tris- $\mathrm{HCl}$, $\mathrm{pH} 7.0,20 \%$ glycerol, $5 \%$ mercaptoethanol, $0.01 \mathrm{mg} / \mathrm{mL}$ bromphenol blue) and heated at $100^{\circ} \mathrm{C}$ for $3 \mathrm{~min}$. Samples were subjected to $7.5 \%$ SDS-PAGE, and resolved proteins were transferred to nitrocellulose membranes. Immunoblotting was then performed with specific affinity-purified rat PEPT1 and PEPT2 antisera developed in our laboratory (12). Membranes were blocked with $6 \%$ nonfat dry milk in TBS-T (20 $\mathrm{mM}$ Tris- $\mathrm{HCl}, \mathrm{pH} 7.5,150 \mathrm{mM} \mathrm{NaCl}, 0.1 \%$ Tween 20) for $2 \mathrm{~h}$ and then probed with polyclonal antibody (1:1000 dilution in blocking buffer) for $1.5 \mathrm{~h}$, both steps at room temperature. The membranes were washed three times in TBS-T, blocked again, and then incubated with the second antibody, peroxidaseconjugated goat anti-rabbit IgG, 1:5000 dilution (Vector Laboratories, Burlingame, CA, U.S.A.). The membranes were then washed several times in TBS-T, and the bound antibody was detected with an enhanced chemiluminescence immunoblot- 
ting system (ECL Plus, Amersham Life Science, Arlington Heights, IL, U.S.A.). Intensity of the signal was quantified using National Institutes of Health Image v1.61/PPC software (Bethesda, MD, U.S.A.). Preliminary studies showed linearity of the immunoblot assay from 1 to $200 \mu \mathrm{g}$ of intestine and kidney membrane protein.

\section{RESULTS}

Expression of PEPT1 in the rat small intestine and colon. Quantitative Northern analyses of PEPT1 RNA were performed in intestinal tissue segments from embryonic d 17 through postpartum d 75 (adult) rats. As shown in Figure 1, PEPT1 transcripts were evident in the small intestine as early as d 20 of fetal life. PEPT1 mRNA levels increased rapidly at birth in the duodenum, jejunum, and ileum, and were maximal by $\mathrm{d} 3-5$. PEPT1 levels then fell rapidly to $11-13 \%$ of maximal expression by $\mathrm{d} 14$ and then rose again to $23-58 \%$ of maximal expression by $\mathrm{d} 24$, about the time of weaning. This increase was most notable in the ileum. Adult mRNA levels of PEPT1 were approximately $25 \%$ of the maximal expression observed at d 3-5. Significant expression of PEPT1 mRNA was observed in the colon at d $1-5$, followed by a rapid decrease to very low levels at $d 7$ and to undetectable levels at $d 14$. A similar pattern of expression was observed for PEPT1 protein. In all small intestinal segments (Fig. 2), embryonic d 20 levels were detectable but low and expression was maximal 3-5 d after birth. PEPT1 protein then decreased sharply, but at d 24 levels were $59-88 \%$ of maximal expression. At d 75 (adult), levels were approximately $70 \%$ of maximal expression. PEPT1 protein was observed in the colon at d 1-5, but expression was undetectable thereafter.

Expression of PEPT1 and PEPT2 in the rat kidney. The expression pattern of PEPT1 and PEPT2 were similar in kidney but in sharp contrast to that observed for PEPT1 in the small intestine and colon. As observed in Figure 3, the mRNA of both peptide transporters was readily detected in fetal kidneys as early as embryonic $\mathrm{d} 17$. mRNA levels then climbed steadily to a postpartum value of $70 \%$ maximal expression at $\mathrm{d} 14$. An abrupt increase was then observed, reaching a maximal expression at $\mathrm{d} 24$. Peptide transporter mRNA then declined to reach values as an adult of $63-72 \%$ maximal expression. PEPT1 and PEPT2 proteins showed a monotonic increase in their expression from fetal d 20 to d 75 (adult). By d 7, protein levels were approximately $86 \%$ of maximal expression, and by d 14 , protein levels were $92-98 \%$ of maximal expression (Fig. 4).

\section{DISCUSSION}

Few studies have investigated the ability of the small intestine to transport peptides in developing animals $(17,18)$. In one study (17), age-dependent changes in the absorption of dipeptides and their constituent amino acids were evaluated in isolated everted intestinal segments (i.e. jejunum and ileum) of guinea pig. It was observed that GlyGly and glycyl-L-leucine influxes were significantly greater in sucklings $(3-4 \mathrm{~d}, 80-120$ g) than in weanlings $(10-14 \mathrm{~d}, 160-220 \mathrm{~g})$, which, in turn, were greater than in adults $(350-500 \mathrm{~g})$. Kinetically, the developmental change in jejunal GlyGly influx was related to a decrease in maximal transport capacity (i.e. $V_{\max }, 51$ and 20 $\mathrm{nmol} \cdot \mathrm{cm}^{-2} \cdot \mathrm{min}^{-1}$ in sucklings and adults, respectively) as opposed to a change in substrate affinity (i.e. $K_{m}, 2.4$ and 2.1 $\mathrm{mM}$ in sucklings and adults, respectively). In the other study (18), uptake of GlyPro and glycine was evaluated in vitro in the jejunum and ileum of rabbits from the 25th day of gestational age into adulthood. Results show a gradual increase of GlyPro influx in both jejunum and ileum from the earliest fetal period studied, with a striking perinatal peak. After the first $6 \mathrm{~d}$ of postnatal life, the uptake of GlyPro declined continually, reaching minimum values as an adult $(>3 \mathrm{mo})$. In contrast, glycine uptake did not show a well-defined developmental pattern in jejunal and ileal tissues. Further, the uptake of GlyGly was substantially higher than that of glycine in fetal (25-30 d gestational age), newborn (1-6 d old), and suckling or weaned ( $10-50 \mathrm{~d}$ old) rabbits. These two studies point to developmental changes in the activity of the intestinal dipeptide carrier, and the preferential uptake of small peptides over their free amino acids in newborns and infants.

In a subsequent study (5), the cloning, tissue distribution, and expression of rat PEPT1 in jejunum was examined during development. Northern blot analyses revealed that intestinal PEPT1 mRNA levels were highest in 4-d-old rats, and then decreased reaching the adult level (d 70) by d 28 after birth. Although providing the first molecular evidence of developmental changes in the rat intestinal oligopeptide transporter, this study was limited in that only jejunal tissue was sampled and protein levels were not determined.

In the present study, we characterized the developmental expression of PEPT1 mRNA and protein in the duodenum, jejunum, ileum, and colon of the rat. We also characterized PEPT1 and PEPT2 expression (mRNA and protein) in the developing rat kidney. With respect to the small intestine, our findings support a molecular basis for age-related alterations in dipeptide transport. In this regard, our mRNA and protein results in rat are similar to the activity data reported in guinea pig (17) and rabbit (18). In general, maximal effects are observed in the small intestine of newborns (within 1 wk of birth) and rapidly fall during the next week. Expression levels then begin to increase at about d 21, especially in the ileum. Interestingly, PEPT1 was expressed and developmentally regulated in the colon during the first few days of life. This is a novel finding because PEPT1 is not expressed in the colon of adult rats [(26), this study]. It should be appreciated, however, that amino acid transporters are also expressed in the colon of newborn pigs and, so it appears, seem to parallel that of PEPT1 (27-29).

To our knowledge, no studies have examined whether or not oligopeptide transporters are developmentally regulated in the kidney. This information is important given the role of the kidney in peptide retention and, in concert with the intestine, the regulation of di- and tripeptide levels in plasma. In the present study, mRNA and protein levels of PEPT1 and PEPT2 showed a similar pattern in their age-dependent expression. In general, expression levels increased steadily over time to reach an asymptote by 2 wk after birth. However, the abrupt change in mRNA at d 24 was not reflected by a similar change in protein, suggesting posttranscriptional control of this process. 


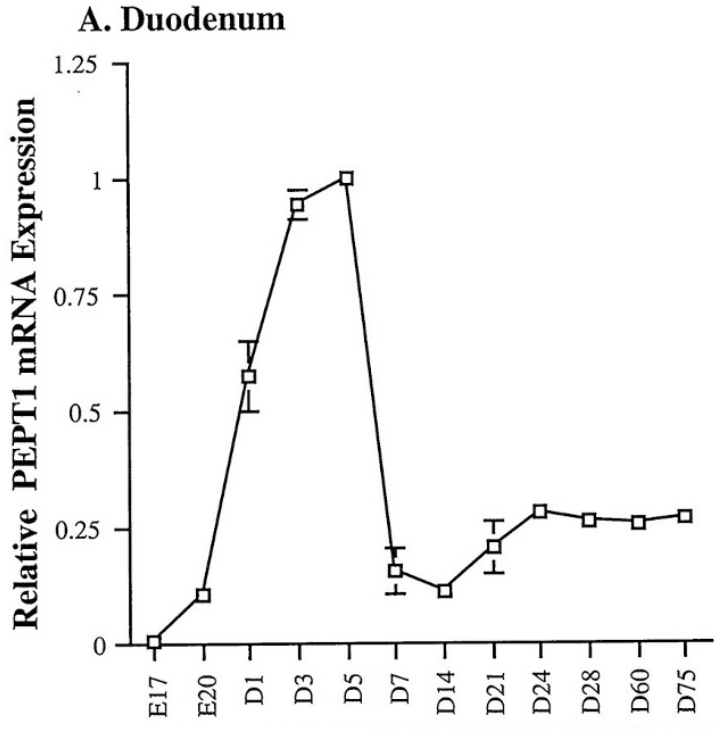

PEPT1

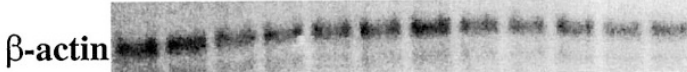

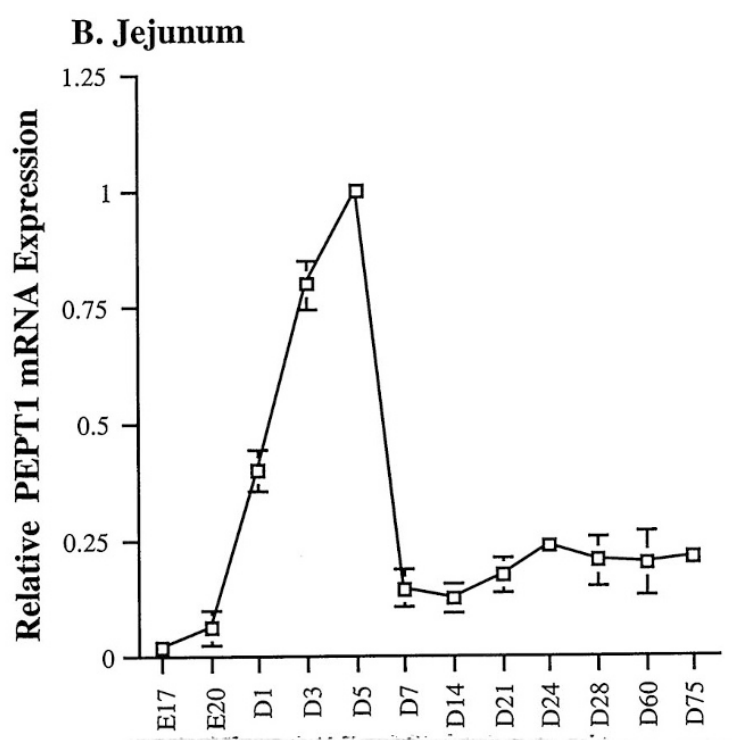

PEPT1

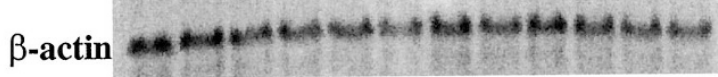

D. Colon

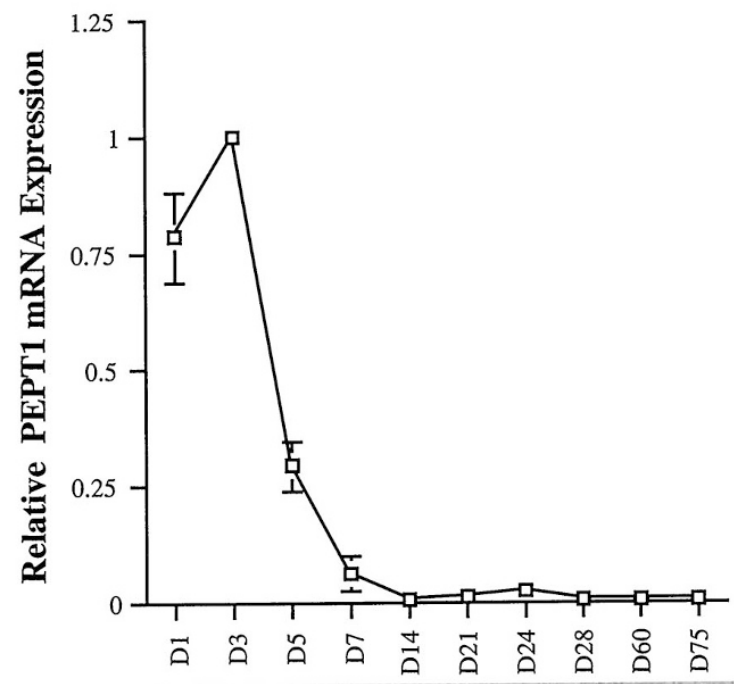

PEPT1

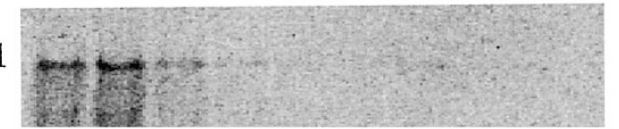

$\beta$-actin

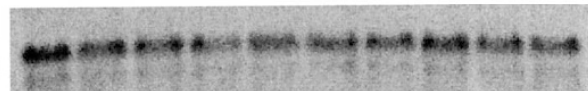

Figure 1. High-stringency Northern blot analysis of PEPT1 mRNA in the small intestine (duodenum, jejunum, and ileum) and colon of developing rats. Total cellular RNA was extracted from pooled tissue samples at 17 and $20 \mathrm{~d}$ of gestation (E17, E20) and at 1-75 d after birth (D1-D75). Each lane contains 15 $\mu \mathrm{g}$ of total RNA. PEPT1 mRNA levels were standardized to $\beta$-actin mRNA. Autoradiographs were subjected to scanning densitometry, and mRNA abundance was expressed relative to that of maximal expression (i.e. d 5 for duodenum and jejunum; $\mathrm{d} 3$ for ileum and colon). Data are reported as mean \pm SEM of two to three preparations, with three to 18 animals per preparation.

Overall, it appears that nutrition may play a less prominent role in the renal expression of PEPT1 and PEPT2.

Several recent studies have examined the regulatory influence of diet on the expression or activity of peptide transport- ers. Thus, it was observed that PEPT1 activity $\left(V_{\max }\right.$ increased, $K_{m}$ unchanged) and protein and mRNA levels were upregulated when Caco-2 cells were incubated in a peptide-rich medium ( $4 \mathrm{mM}$ glycyl-L-glutamine replacing $4 \mathrm{mM}$ glutamine) 


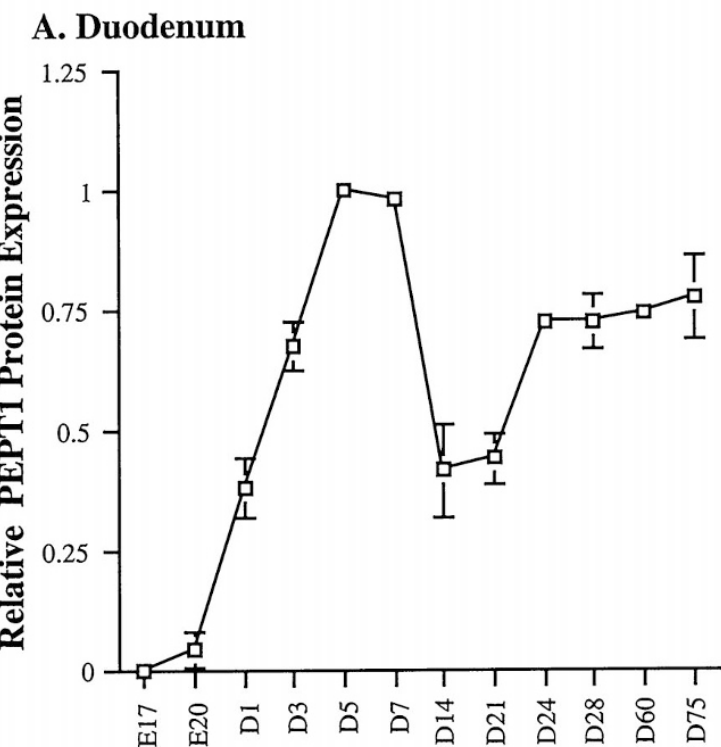

PEPT1 iो

\section{B. Jejunum}

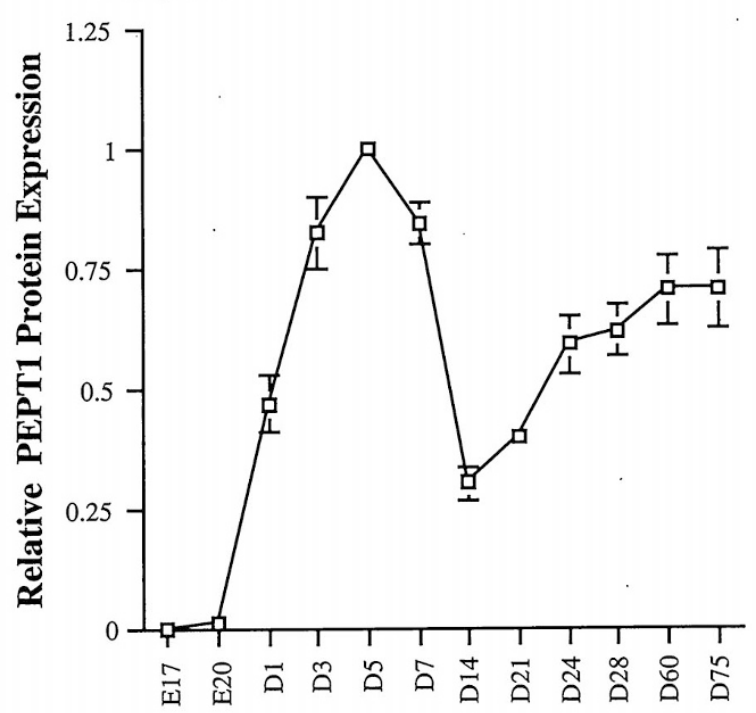

\section{PEPT1 H4}

D. Colon

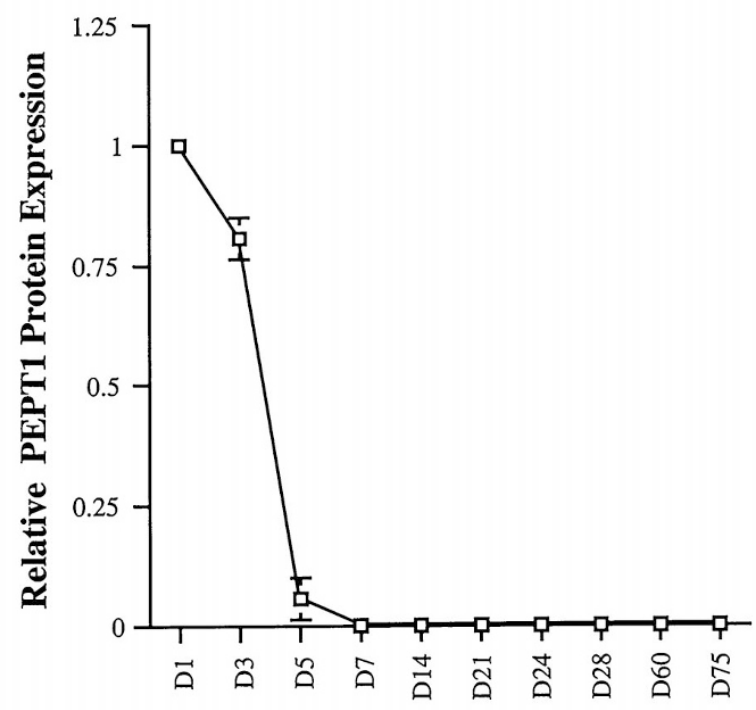

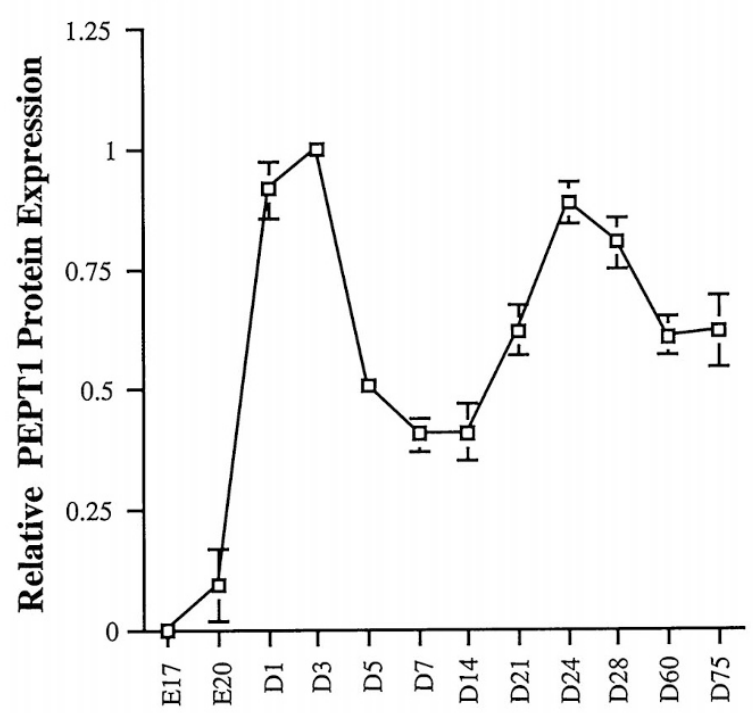

PEPT1

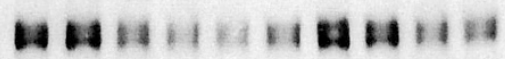

PEPT1

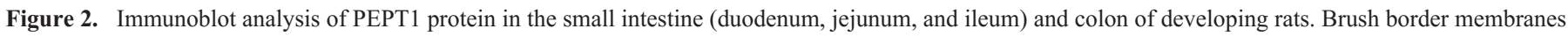
were purified from pooled tissue samples at 17 and $20 \mathrm{~d}$ of gestation (E17, E20) and at 1-75 d after birth (D1-D75). Each lane contains 100 $\mu \mathrm{g}$ of membrane protein, which was incubated with polyclonal antibodies raised against a PEPT1 synthetic peptide (residues 699-710). Autoradiographs were subjected to scanning densitometry, and protein abundance was expressed relative to that of maximal expression (i.e. $\mathrm{d} 5$ for duodenum and jejunum; 3 for ileum; $\mathrm{d}$ for colon). Data are reported as mean \pm SEM of two to three preparations, with three to 18 animals per preparation.

(30). Increased levels of human PEPT1 mRNA were a reflection of both increased transcription and mRNA stability via a signaling pathway acting directly on the enterocyte. In another study (31), it was found that increasing amounts of dietary protein (i.e. casein) enhanced the transport of GlySar in rat ileal brush border membrane vesicles. Feeding of a dipeptide (i.e. glycyl-phenylalanine) or an amino acid (i.e. phenylalanine but not glycine) also stimulated GlySar transport activity $\left(V_{\max }\right.$ 

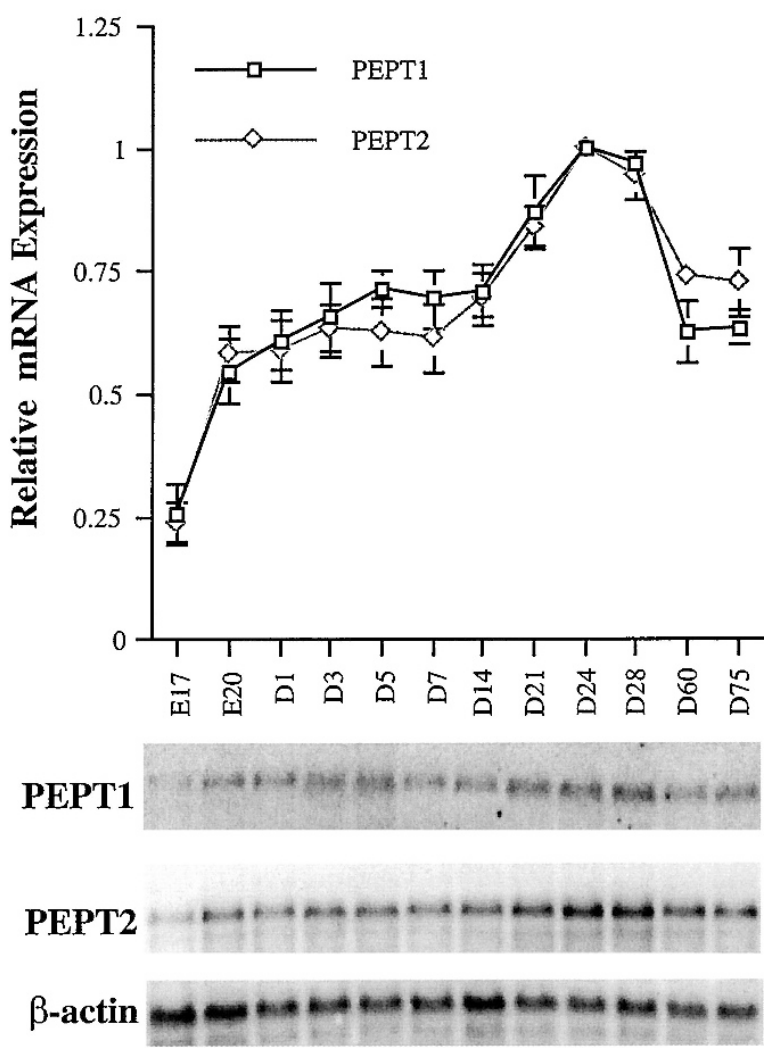

Figure 3. High-stringency Northern blot analysis of PEPT1 and PEPT2 mRNA in the whole kidney of developing rats. Poly(A) ${ }^{+}$RNA was extracted from pooled tissue samples at 17 and $20 \mathrm{~d}$ of gestation (E17, E20) and at 1-75 $\mathrm{d}$ after birth (D1-D75). Each lane contains $4 \mu \mathrm{g}$ of poly(A) ${ }^{+}$RNA. PEPT1 and PEPT2 mRNA levels were standardized to $\beta$-actin mRNA. Autoradiographs were subjected to scanning densitometry, and mRNA abundance was expressed relative to that of maximal expression (i.e. d 24). Data are reported as mean \pm SEM of three preparations, with three to 18 animals per preparation.

increased but not $K_{m}$ ) compared with rats fed a protein-free diet, along with concomitant changes in PEPT1 mRNA and protein levels. This finding suggested that up-regulation of dipeptide transport activity by dietary protein was caused by transcriptional activation of the PEPT1 gene by selective amino acids and dipeptides in the diet. In a third study (32), it was observed that short-term starvation (4-d fast but free access to water) markedly increased the amount of PEPT1 protein present in rat jejunum, whereas dietary administration of amino acids reduced PEPT1 protein. These results were subsequently confirmed by a preliminary report (33) in which the functional and molecular expression of PEPT1 was upregulated after a brief fast (i.e. 1-d fast but free access to water) in rat jejunal brush border membrane vesicles. As a whole, these studies (30-33) confirm and extend the existing evidence that dietary regulation has a profound effect on peptide absorption and expression in the intestine.

After birth, the developing small intestine and colon face major changes in the functional demands that are placed on them. In particular, the placenta is replaced by the intestines as the site of nutrient procurement, and, at the time of weaning, animals make major changes in their diet. In the case of rats, a high-protein milk diet is often replaced with an adult diet
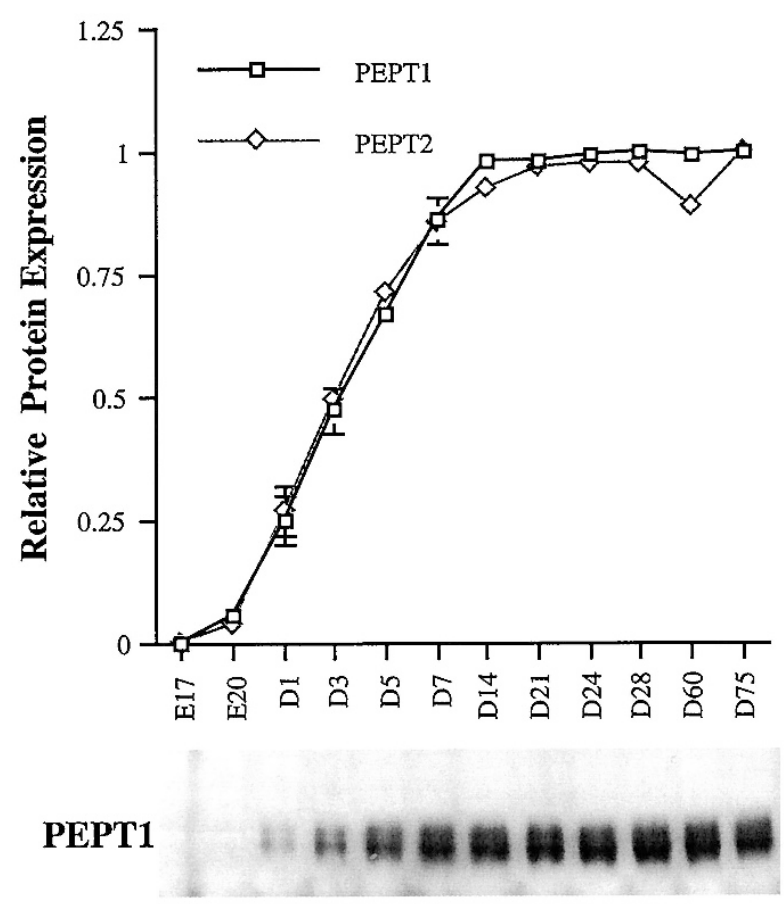

\section{PEPT2}

Figure 4. Immunoblot analysis of PEPT1 and PEPT2 protein in the whole kidney of developing rats. Brush border membranes were purified from pooled tissue samples at 17 and $20 \mathrm{~d}$ of gestation (E17, E20) and at 1-75 d after birth (D1-D75). Each lane contains $100 \mu \mathrm{g}$ of membrane protein, which was incubated with polyclonal antibodies raised against a PEPT1 or PEPT2 synthetic peptide (residues $699-710$ or 718-729, respectively). Autoradiographs were subjected to scanning densitometry, and protein abundance was expressed relative to that of maximal expression (i.e. $\mathrm{d} 75$ ). Data are reported as mean \pm SEM of three preparations, with three to 18 animals per preparation.

typically containing more carbohydrate than protein. Our findings, showing up-regulation of PEPT1 in the first week of life, are consistent with the influence of a high-protein diet on peptide expression. In addition, the increased expression of PEPT1 at weaning (especially in ileum) may be related to an adaptive response to the reduced protein diet or nourishment at this time period. In both cases, it appears that developmental changes occur such that the chances of survival are optimized. Although the kidney is not as regulated as intestine and colon with respect to diet, it is unclear what effect ontogenesis may have on peptidase activity and the associated retention of constituent amino acids in this organ. It is also unclear how hormonal or neural pathways affect oligopeptide regulation in the developing intestine and kidney. These factors were beyond the scope of the present study, but may be important as suggested previously $(11,20,34)$.

In summary, our studies have provided, for the first time, the developmental expression of peptide transporter mRNA and protein in distinct regions of the small intestine, colon, and kidney in rat. Our findings suggest that intestinal expression of PEPT1 is induced postpartum, possibly by suckling, and again at the time of weaning, and that the colon may participate in 
peptide transport early in life. PEPT1 and PEPT2 expression is less regulated in rat kidney and more pronounced in older animals. Overall, these results may have important implications for protein nutrition, as well as for drug disposition and targeting of peptides or mimetics in the young.

\section{REFERENCES}

1. Fei Y-J, Kanai Y, Nussberger S, Ganapathy V, Leibach FH, Romero MF, Singh SK, Boron WF, Hediger MA 1994 Expression cloning of a mammalian proton-coupled oligopeptide transporter. Nature 368:563-566

2. Boll M, Markovich D, Weber W-M, Korte H, Daniel H, Murer H 1994 Expression cloning of a cDNA from rabbit small intestine related to proton-coupled transport of peptides, $\beta$-lactam antibiotics and ACE-inhibitors. Pflugers Arch 429:146-149

3. Boll M, Herget M, Wagener M, Weber WM, Markovich D, Biber J, Clauss W, Murer H, Daniel H 1996 Expression cloning and functional characterization of the kidney cortex high-affinity proton-coupled peptide transporter. Proc Natl Acad Sci USA 93:284-289

4. Saito H, Okuda M, Terada T, Sasaki S, Inui K-I 1995 Cloning and characterization of a rat $\mathrm{H}^{+}$/peptide cotransporter mediating absorption of $\beta$-lactam antibiotics in intestine and kidney. J Pharmacol Exp Ther 275:1631-1637

5. Miyamoto K-I, Shiraga T, Morita K, Yamamoto H, Haga H, Taketani Y, Tamai I, Sai Y, Tsuji A, Takeda E 1996 Sequence, tissue distribution and developmental changes in rat intestinal oligopeptide transporter. Biochim Biophys Acta 1305:34-38

6. Saito H, Terada T, Okuda M, Sasaki S, Inui K-I 1996 Molecular cloning and tissue distribution of rat peptide transporter PEPT2. Biochim Biophys Acta 1280:173-177

7. Liang R, Fei Y-J, Prasad PD, Ramamoorthy S, Han H, Yang-Feng TL, Hediger MA, Ganapathy V, Leibach FH 1995 Human intestinal $\mathrm{H}^{+}$/peptide cotransporter: cloning, functional expression, and chromosomal localization. J Biol Chem 270:6456-6463

8. Liu W, Liang R, Ramamoorthy S, Fei Y-J, Ganapathy ME, Hediger MA, Ganapathy V, Leibach FH 1995 Molecular cloning of PEPT2, a new member of the $\mathrm{H}^{+}$/peptide cotransporter family, from human kidney. Biochim Biophys Acta 1235:461-466

9. Yamashita T, Shimada S, Guo W, Sato K, Kohmura E, Hayakawa T, Takagi T, Tohyama M 1997 Cloning and functional expression of a brain peptide/histidine transporter. J Biol Chem 272:10205-10211

10. Adibi SA 1997 The oligopeptide transporter (PEPT1) in human intestine: biology and function. Gastroenterology 113:332-340

11. Adibi SA 1997 Renal assimilation of oligopeptides: physiological mechanisms and metabolic importance. Am J Physiol 272:E723-E736

12. Shen H, Smith DE, Yang T, Huang YG, Schnermann JB, Brosius III FC 1999 Localization of PEPT1 and PEPT2 proton-coupled oligopeptide transporter mRNA and protein in rat kidney. Am J Physiol 276:F658-F665

13. Terada T, Saito H, Mukai M, Inui K-I 1997 Recognition of $\beta$-lactam antibiotics by rat peptide transporters, PEPT1 and PEPT2, in LLC-PK 1 cells. Am J Physiol 273:F706F711

14. Zhu T, Chen X-Z, Steel A, Hediger MA, Smith DE 2000 Differential recognition of ACE inhibitors in Xenopus laevis oocytes expressing rat PEPT1 and PEPT2. Pharm Res 17:526-532
15. Han H-K, de Vrueh RLA, Rhie JK, Covitz K-MY, Smith PL, Lee C-P, Oh D-M, Sadée W, Amidon GL 1998 5'-Amino acid esters of antiviral nucleosides, acyclovir, and AZT are absorbed by the intestinal PEPT1 peptide transporter. Pharm Res 15:1154-1159

16. Ganapathy ME, Huang W, Wang H, Ganapathy V, Leibach FH 1998 Valacyclovir: a substrate for the intestinal and renal peptide transporters PEPT1 and PEPT2. Biochem Biophys Res Commun 246:470-475

17. Himukai M, Konno T, Hoshi T 1980 Age-dependent change in intestinal absorption of dipeptides and their constituent amino acids in the guinea pig. Pediatr Res 14:1272-1275

18. Guandalini S, Rubino A 1982 Development of dipeptide transport in the intestinal mucosa of rabbits. Pediatr Res 16:99-103

19. Vazquez JA, Daniel H, Adibi SA 1993 Dipeptides in parenteral nutrition: from basic science to clinical applications. Nutr Clin Pract 8:9-105

20. Ganapathy V, Brandsch M, Leibach FH 1994 Intestinal transport of amino acids and peptides. In: Johnson LR (ed) Physiology of the Gastrointestinal Tract, 3rd Ed. Raven Press, New York, pp 1773-1794

21. Leibach FH, Ganapathy V 1996 Peptide transporters in the intestine and the kidney. Annu Rev Nutr 16:99-119

22. Chomczynski P, Sacchi N 1987 Single-step method of RNA isolation by acid guanidinium thiocyanate-phenol-chloroform extraction. Anal Biochem 162:156-159

23. Chomczynski P 1993 A reagent for the single-step simultaneous isolation of RNA, DNA and proteins from cell and tissue samples. Biotechniques 15:532-534, 536-537

24. Akarawut W, Lin C-J, Smith DE 1998 Noncompetitive inhibition of glycylsarcosine transport by quinapril in rabbit renal brush border membrane vesicles: effect on high-affinity peptide transporter. J Pharmacol Exp Ther 287:684-690

25. Bradford MM 1976 A rapid and sensitive method for the quantitation of microgram quantities of protein utilizing the principle of protein-dye binding. Anal Biochem $72: 248-254$

26. Ogihara H, Saito H, Shin B-C, Terada T, Takenoshita S, Nagamachi Y, Inui K-I, Takata K 1996 Immuno-localization of $\mathrm{H}^{+}$/peptide cotransporter in rat digestive tract. Biochem Biophys Res Commun 220:848-852

27. James PS, Smith MW 1976 Methionine transport by pig colonic mucosa measured during early post-natal development. J Physiol (Lond) 262:151-168

28. Jarvis LG, Morgan G, Smith MW, Wooding FBP 1977 Cell replacement and changing transport function in the neonatal pig colon. J Physiol (Lond) 273:717-729

29. Sepúlveda FV, Smith MW 1979 Different mechanisms for neutral amino acid uptake by new-born pig colon. J Physiol (Lond) 286:479-490

30. Walker D, Thwaites DT, Simmons NL, Gilbert HJ, Hirst BH 1998 Substrate upregulation of the human small intestinal peptide transporter, hPEPT1. J Physiol (Lond) 507:697-706

31. Shiraga T, Miyamoto K-I, Tanaka $H$, Yamamoto H, Taketani Y, Morita K, Tamai I, Tsuji A, Takeda E 1999 Cellular and molecular mechanisms of dietary regulation on rat intestinal $\mathrm{H}^{+}$/peptide transporter PEPT1. Gastroenterology 116:354-362

32. Ogihara H, Suzuki T, Nagamachi Y, Inui K-I, Takata K 1999 Peptide transporter in the rat small intestine: ultrastructural localization and the effect of starvation and administration of amino acids. Histochem J 31:169-174

33. Thamotharan M, Bawani SZ, Zhou X, Adibi SA 1999 Functional and molecular expression of intestinal oligopeptide transporter (PEPT1) after a brief fast. Metabolism 48:681-684

34. Thamotharan M, Bawani SZ, Zhou X, Adibi SA 1999 Hormonal regulation of oligopeptide transporter PEPT1 in a human intestinal cell line. Am J Physiol 276:C821-C826 